\title{
Communication
}

[Comunicação]

\section{Evaluation of different sites for blood collection for $\beta$-hydroxybutyrate assessment in dairy cows using hand-held meter}

\author{
[Avaliação de diferentes locais de coleta de sangue para avaliação de $\beta$-hidroxibutirato em vacas \\ de leite usando aparelho portátil automático] \\ E.A. Alvarenga ${ }^{1}$, G.H.F.A. Moreira ${ }^{2}$, E.J. Facury Filho ${ }^{3}$, F.O.P. Leme $^{3}$, \\ T.F. Moreira* , A.U. Carvalho ${ }^{3}$ \\ ${ }^{1}$ Rehagro - Belo Horizonte, MG \\ ${ }^{2}$ UniBH - Belo Horizonte, MG \\ ${ }^{3}$ Universidade Federal de Minas Gerais - Belo Horizonte, MG \\ ${ }^{4}$ Universidade Vila Velha - Vila Velha, ES
}

Subclinical ketosis is a metabolic disease with high prevalence and impact on dairy production and predisposes the animal to health-impairing outcomes (Raboisson et al., 2014). Subclinical ketosis occurs mainly in early lactation in consequence of the negative energy balance and can reach prevalence up to $43 \%$ in some herds (Suthar et al., 2013). Measuring $\beta$ hydroxybutyrate (BHBA) blood concentrations at the individual and herd level is an important tool in dairy farms, firstly because it enables early diagnosis and prompt treatment of ketosis which can significantly reduce the economic losses derived by this condition (McArt et al., 2012). Second because BHBA concentration is a useful indicator of hepatic and energy metabolism in transition cows and can be used for improve stock management efficiency especially in the most challenging time in the cows' production cycle, the transition period (Drackley et al., 2001; Raboisson et al., 2014).

The BHBA measurement is usually performed in laboratories and sample care handling, logistics demand and time for issuing a result make this an inconvenient practice. However, currently hand-held device for determining BHBA are available enabling fast results with high correlation with laboratory tests (Iwersen et al.,
2009; Voyvoda and Erdogan, 2010; Panousis et al., 2012; Doré et al., 2013).

The usual site for blood collection to determine BHBA is the coccygeal vein, but it required that the animal be well contained in order to take the sample, thus increasing the work and time expended. Considering the above mentioned aspects, an alternative site for blood collection and the use of a hand-held device for BHBA measurement can make monitoring subclinical ketosis in dairy herds easier and less time consuming. Thus, the primary objective of this study was to compare different sites for BHBA sample collection and test one electronic handheld device comparing it with laboratory results.

The study was approved by the Ethic Committee for Animal Experimentation of the Universidade Fereral de Minas Gerais. Six Holstein cows between the second and the fourth lactation were used. Cows were housed in free stall barns with sand bedding and grooved floors in Minas Gerais Estate, Brazil. Herd average milk yield was $8235 \mathrm{~kg}$ per lactation. Cows were fed twice per day a TMR based on corn silage, fresh Tifton grass and concentrate with corn and soy products. 150 .

Recebido em 13 de julho de 2017

Aceito em 18 de agosto de 2018

* Autor para correspondência (corresponding author)

E-mail: tiagofacuryvet@gmail.com 
Blood samples were taken 4 to 5 hours after feeding on the $2^{\text {nd }}, 5^{\text {th }}, 10^{\text {th }}, 15^{\text {th }}$ and $21^{\text {st }}$ days post-calving. Blood samples were drawn from tip of the tail, jugular, coccygeal and mammary veins. For venous or arteriosus blood sampling were used a $3 \mathrm{ml}$ syringe and a lancet of $28 \mathrm{~mm}$ for the tip of the tail. A drop of whole blood was transferred into the front edge of the strip which was already inserted in the hand-held device (Trade name in Brazil: Optium Xceed ${ }^{\circledR}$ and elsewhere Precision Xtra ${ }^{\circledR}$, Abbott Laboratories Brazil). The test results were displayed 10s after application of the blood and values recorded onto a data capture form. The same device was used for all samples.

For laboratory analysis, blood samples were drawn from the jugular vein with $5 \mathrm{ml}$ vacuum tubes without anticoagulant. Blood samples were centrifuged (10min, 3.800rpm) and serum was stored in 2 aliquots at $-20^{\circ} \mathrm{C}$. Serum BHBA concentrations were determined by colorimetric enzymatic reaction (Ranbut D-3-hydroxybutyrate kit, Randox Laboratories Brazil, São Paulo, Brazil) in an automated chemistry analyzer (Cobas Mira Plus, Roche Diagnostics International, São Paulo Brazil).

Data were analyzed using the software SAEG 9.1 (2007). The mean serum concentration of BHBA of the different sampling sites and the analysis method were compared by SNK and F test, respectively, with 5\% significance. Correlation coefficient was calculated between BHBA concentration measured from jugular blood with the hand-held divice and the laboratory test.

The BHBA concentrations measured in jugular blood with the portable device Optium Xceed ${ }^{\circledR}$ and by spectrophotometry were similar $(\mathrm{P}>0.05)$ at all sampling time and presented a strong significant correlation of 0.83 . This indicates a good reliability similar to others researches who also endorse the use of the portable device as an analytical method for BHBA measurement (Iwersen et al., 2009; Voyvoda and Erdogan, 2010; Panousis et al., 2012; Kanz et al., 2015).

Regarding blood collection sites, BHBA concentration was similar in blood drown from jugular veins, coccygeal veins and tip of the tail while mammary vein was lower than all others sampling sites in all studies moments (Table 1). To our knowledge this is the first study evaluating capillary blood from the tip of the tail for diagnosis of subclinical ketosis. In another study, capillary blood drawn from the external vulva was considered suitable to detect subclinical ketosis (Kanz et al., 2015).

Table 1. Differences between $\beta$-hydroxybutyrate (BHBA) concentrations $( \pm \mathrm{SD})$ in whole blood samples obtained from the tip of the tail, coccygeal vein, mammary vein and jugular vein using hand-held device in different sampling times after calving in dairy cows

\begin{tabular}{lcccccc}
\hline Place of & \multicolumn{5}{c}{ Days post-calving } & \multirow{2}{*}{ Total } \\
\cline { 2 - 5 } collection & 2 & 5 & 10 & 15 & 21 & \\
\hline \multirow{2}{*}{ Tip of the tail } & $0.83^{\mathrm{a}}$ & $1.27^{\mathrm{a}}$ & $0.77^{\mathrm{a}}$ & $0.67^{\mathrm{a}}$ & $0.70^{\mathrm{a}}$ & $0.85^{\mathrm{a}}$ \\
& $( \pm 0.19)$ & $( \pm 0.72)$ & $( \pm 0.18)$ & $( \pm 0.15)$ & $( \pm 0.21)$ & $( \pm 0.42)$ \\
Coccygeal vein & $0.67^{\mathrm{a}}$ & $1.08^{\mathrm{a}}$ & $0.73^{\mathrm{a}}$ & $0.62^{\mathrm{a}}$ & $0.65^{\mathrm{a}}$ & $0.75^{\mathrm{a}}$ \\
& $( \pm 0.21)$ & $( \pm 0.71)$ & $( \pm 0.16)$ & $( \pm 0.17)$ & $( \pm 0.15)$ & $( \pm 0.39)$ \\
Mammary vein & $0.53^{\mathrm{b}}$ & $0.93^{\mathrm{b}}$ & $0.52^{\mathrm{b}}$ & $0.48^{\mathrm{b}}$ & $0.40^{\mathrm{b}}$ & $0.57^{\mathrm{b}}$ \\
& $( \pm 0.19)$ & $( \pm 0.74)$ & $( \pm 0.21)$ & $( \pm 0.23)$ & $( \pm 0.15)$ & $( \pm 0.42)$ \\
Jugular vein & $0.65^{\mathrm{a}}$ & $1.13^{\mathrm{a}}$ & $0.72^{\mathrm{a}}$ & $0.62^{\mathrm{a}}$ & $0.67^{\mathrm{a}}$ & $0.76^{\mathrm{a}}$ \\
& $( \pm 0.22)$ & $( \pm 0.76)$ & $( \pm 0.11)$ & $( \pm 0.19)$ & $( \pm 0.20)$ & $( \pm 0.42)$ \\
\hline
\end{tabular}

Presence of a different superscript indicates a statistical difference.

Coccygeal vein is the usual site for blood collection in cattle, because of his practical advantage compares to jugular vein (Duffield et al., 2000; Doré et al., 2013; Kanz et al., 2015). However, it still requires animal containment. Methods of sampling venous or arteriosus blood have another disadvantage of being more invasive compared with milk and urine based systems. Futhermore, some countries have regulations that prohibit laypersons to perform blood sampling (Kanz et al., 2015). Based on the present results, capillary blood from the tip of the tail can represent a good alternative for blood sampling requiring little work and training. The only consideration is that it requires attention to cleanliness because dirt and moisture could 
interfere in the results. The experiment was conducted over a period of favorable conditions for maintaining a good cleanliness score, making any interference in this direction unlikely.

Blood samples from the mammary vein presented lower BHBA concentration, primarily caused by the use of ketone bodies for milk fatty acid synthesis (Drackley et al., 2001). In this way, its use is not recommended once it can lead to false negative results.
Concluding, tip of the tail, jugular and coccygeal veins can be used as a site for blood collection in the evaluation of BHBA as a monitoring tool in dairy herds. Because of practical reasons, coccygeal vein and point of tail can be considered the best choices for blood sampling.

Keywords: dairy cows, ketosis, transition period, diagnosis

\section{RESUMO}

Cetose subclínica é uma grande preocupação em rebanhos leiteiros, e seu diagnóstico e prevenção podem ter um grande impacto na saúde animal. Este estudo comparou quatro locais diferentes para a coleta de amostras de sangue (jugular, veias mamárias e coccígeas e ponta da cauda) para medição de $\beta$-hidroxibutirato (BHBA), usando-se um medidor portátil automático. Foram utilizadas seis vacas Holandesas, e a coleta de sangue foi feita no segundo, quinto, $10^{\circ}$, $15^{\circ}$ e $21^{\circ}$ dias pós-parto. Os resultados do medidor portátil foram semelhantes aos resultados do laboratório e apresentaram uma correlação forte de 0,83. As concentrações séricas de BHBA nas amostras de sangue coletadas na ponta da cauda, na jugular e na coccígea foram semelhantes. No entanto, o sangue retirado da veia mamária tinha uma concentração mais baixa. Portanto, as amostras de sangue para aferição de BHBA podem ser recolhidas nas veias jugular e coccígeas e na ponta da cauda, sendo as duas últimas as opções mais fáceis para monitorar o BHBA em rebanho leiteiro.

Palavras-chave: vacas leiteiras, cetose, período de transição, diagnóstico

\section{REFERENCES}

DORÉ, V.; DUBUC, J.; BÉLANGER, A.M.; BUCZINSKI, S. Short communication: evaluation of the accuracy of an electronic on-farm test to quantify blood $\beta$-hydroxybutyrate concentration in dairy goats. J. Dairy Sci., v.96, p.4505-4507, 2013.

DRACKLEY, J.K.; OVERTON, T.R.; DOUGLAS, G.N. Adaptations of glucose and long-chain fatty acid metabolism in liver of dairy cows during the periparturient period. J. Dairy Sci., v.84, p.E100E112, 2001.

IWERSEN, M.; FALKENBERG, U.; VOIGTSBERGER, R. et al. Evaluation of an electronic cowside test to detect subclinical ketosis in dairy cows. J. Dairy Sci., v.92, p.2618-2624, 2009.

KANZ, P.; DRILLICH, M.; KLEIN-JÖBSTL, D. et al. Suitability of capillary blood obtained by a minimally invasive lancet technique to detect subclinical ketosis in dairy cows by using 3 different electronic hand-held devices. J. Dairy Sci., v.98, p.1$11,2015$.
MCART, J.A.A.; NYDAM, D.V.; OETZEL, G.R. Epidemiology of subclinical ketosis in early lactation dairy cattle. J. Dairy Sci., v.95, p.5056-5066, 2012.

PANOUSIS, N.; BROZOS, C.; KARAGIANNIS, I. et al. Evaluation of precision Xceed meter for on-site monitoring of blood B-hydroxybutyric acid and glucose concentrations in dairy sheep. Res. Vet. Sci., v.93, p.435-439, 2012.

RABOISSON, D.; MOUNIÉ, M.; MAIGNÉ, E. Diseases, reproductive performance, and changes in milk production associated with subclinical ketosis in dairy cows: a meta-analysis and review. J. Dairy Sci., v.97, p.7547-7563, 2014.

SISTEMA para análises estatísticas-SAEG. Versão 9.1. Viçosa: UFV / Fundação Arthur Bernardes, 2007. 142p.

SUTHAR, V.S.; CANELAS-RAPOSO, J.; DENIZ, A.; HEUWIESER, W. Prevalence of subclinical ketosis and relationships with postpartum diseases in European dairy cows. J. Dairy Sci., v.96, p.2925-2938, 2013.

VOYVODA, H.; ERDOGAN, H. Use of a hand-held meter for detecting subclinical ketosis in dairy cows. Res. Vet. Sci., v.89, p.344-351, 2010. 